\title{
Artikel
}

\section{De redelijkheid en billijkheid en de verdeling van de gemeenschap van nalatenschap}

\author{
Prof. dr. S. Perrick*
}

\section{Inleiding}

De redactie van dit tijdschrift heeft mij voor dit themanummer een onderwerp toebedeeld dat weinig theoretische vragen opwerpt en dat ik in een kort bestek kan behandelen. Immers, op grond van artikel 3:166 lid 3 van het Burgerlijk Wetboek (BW) is op de rechtsbetrekkingen tussen de deelgenoten artikel 6:2 BW van overeenkomstige toepassing. Dat betekent dat:

a. de deelgenoten verplicht zijn zich jegens elkaar te gedragen overeenkomstig de eisen van redelijkheid en billijkheid; en

b. een tussen de deelgenoten krachtens wet, gewoonte of rechtshandeling geldende regel niet van toepassing is, voor zover dit in de gegeven omstandigheden naar maatstaven van redelijkheid en billijkheid onaanvaardbaar zou zijn.

De redelijkheid en billijkheid zullen in het bijzonder hun invloed doen gelden bij de verdeling van een gemeenschap en dus ook bij de verdeling van een gemeenschap van nalatenschap. Vooral de aanvullende werking van de redelijkheid en billijkheid zal zich in de praktijk voordoen bij de verdeling, maar is daartoe niet beperkt. Ook de beperkende werking van de redelijkheid en billijkheid kan zich bij de verdeling doen gelden.

Alvorens in paragraaf 3 aan mijn eigenlijke onderwerp toe te komen, zal ik in paragraaf 2 enkele opmerkingen maken over de gevolgen van het feit dat de redelijkheid en billijkheid de rechtsbetrekkingen tussen de deelge- noten ook voorafgaande aan de verdeling beheersen. In paragraaf 4 attendeer ik erop dat de beperkende werking van de redelijkheid en billijkheid na de verdeling blijft gelden.

Wat voor de deelgenoten van een gemeenschap van nalatenschap geldt, is in beginsel ook van toepassing op de deelgenoten van een ontbonden huwelijksgemeenschap waarvan een nalatenschap deel uitmaakt.

\section{Redelijkheid en billijkheid voorafgaande aan de verdeling}

Titel 3.7 BW geeft een aantal regels die de rechtsbetrekkingen tussen de deelgenoten bepalen. Ik volsta met twee voorbeelden.

Volgens artikel 3:192 BW kunnen tot de gemeenschap van nalatenschap behorende schulden op de goederen van de gemeenschap worden verhaald. Op de verhouding tussen een schuldeiser en een schuldenaar is artikel 6:2 BW van toepassing. Dat geldt ook voor de verhouding tussen een schuldeiser van de nalatenschap en de schuldenaar, waarvoor hier mag worden gelezen de gemeenschap van nalatenschap. Schuldenaar voor het geheel of een gedeelte is ook een erfgenaam, waarbij in dit verband de positie van een erfgenaam die zuiver heeft aanvaard, aandacht verdient. Naar mijn mening verzet artikel 6:2 lid $1 \mathrm{BW}$ zich er niet tegen dat een schuldeiser van de nalatenschap zich op goederen die tot het overig vermogen van de erfgenaam behoren, verhaalt. De schuldeiser is niet verplicht zich eerst te ver- 
halen op de goederen van de gemeenschap. ${ }^{1}$ Maar het kan (zie art. 6:2 lid 2 BW) wel naar maatstaven van redelijkheid en billijkheid onaanvaardbaar zijn dat de schuldeiser zich verhaalt op de goederen die tot het overig vermogen van de erfgenaam behoren. ${ }^{2}$ Hierbij is te denken aan het geval dat de gemeenschapsschuld tot betaling van een geldsom zonder bezwaren uit de gemeenschap kan worden voldaan, terwijl het voor de deelgenoot uiterst bezwaarlijk zou zijn het gedeelte van de schuld dat op hem rust uit zijn overig vermogen te voldoen. ${ }^{3}$ Is de schuldeiser ook deelgenoot, bijvoorbeeld legataris, dan zullen de eisen van redelijkheid en billijkheid veelal meebrengen dat deze eerst verhaal op de gemeenschap zoekt. ${ }^{4}$ De deelgenoot kan verlangen dat deze schuld aan hem wordt voldaan alvorens tot verdeling van de gemeenschap wordt overgegaan (zie art. 3:178 lid 2 BW). In de praktijk zal de schuld wel in het kader van de verdeling worden voldaan. ${ }^{5}$

Een deelgenoot die er belang bij heeft dat een andere deelgenoot gedurende enige tijd geen gebruik kan maken van zijn recht om te allen tijde verdeling van een goed te vorderen, zal in artikel 3:178 lid 3 BW wel voldoende bescherming vinden en geen behoefte hebben om zich te beroepen op artikel 6:2 lid 2 BW.

\section{Redelijkheid en billijkheid en verdeling}

\subsection{Inleiding}

Bij de verdeling spelen de aanvullende werking van de redelijkheid en billijkheid en soms ook de beperkende werking daarvan een grote rol. Ten behoeve van de inzichtelijkheid breng ik een onderverdeling aan, waarbij ik geen volledigheid nastreef.

\subsection{Tijdstip per welk waardering plaatsvindt}

Bij de gemeenschap van nalatenschap zal geen discussie mogelijk zijn over de vraag wat de peildatum is voor de vaststelling van de gemeenschap. Dat is het tijdstip van overlijden van erflater. Voor het bepalen van de peildatum voor de huwelijksgemeenschap is beslissend het tijdstip van ontbinding daarvan. ${ }^{6}$

Aldus ook Hof Den Haag 3 maart 2020, ECLI:NL:GHDHA:2020:410. Zie Asser/Perrick 3-V 2019/69.

3 Rb. Rotterdam 6 maart 2019, ECLI:NL:RBROT:2019:1767 toetst naar mijn mening terecht aan het strenge criterium van art. 6:2 lid $2 \mathrm{BW}$ bij de beoordeling of de vordering van een onterfde erfgename dat de erfgenamen worden veroordeeld om aan haar te betalen wat zij van de nalatenschap te vorderen heeft, dient te worden toegewezen. Zie ook Asser/ Perrick 4 2021/483.

4 Dat vloeit naar mijn mening voort uit art. 6:2 lid 2 BW dat, zo men die wettelijke basis al nodig zou achten, op grond van art. 3:166 lid 3 BW tevens naar analogie van toepassing is op de rechtsbetrekking tussen de deelgenoten, waaronder begrepen de deelgenoot/schuldeiser.

5 Zie Asser/Perrick 4 2021/485.

6 Zie HR 20 december 2013, ECLI:NL:HR:2013:2050, NJ 2014/129, waarin de Hoge Raad besliste dat op grond van de eisen van redelijkheid en billijkheid niet kan worden afgeweken van de peildatum voor het vaststellen van de samenstelling en de omvang van de (ontbonden) huwelijksgemeenschap.
Uiteraard kan de samenstelling van de goederen van de gemeenschap van nalatenschap na het tijdstip van openvallen van de nalatenschap wijzigen. Daarbij is onder meer artikel 3:167 BW, op grond waarvan tot de gemeenschap behoren goederen die geacht moeten worden in de plaats van een gemeenschappelijk goed te treden, van belang. ${ }^{7}$ Tot de gemeenschap behoren voorts de vruchten en andere voordelen van de gemeenschappelijke goederen die door de gemeenschap zijn ontvangen. ${ }^{8}$

Van de vraag wat de peildatum is voor de vaststelling van de samenstelling en de omvang van de gemeenschap dient te worden onderscheiden de vraag wat de peildatum is voor de waardering. De waardering van de op het tijdstip van de verdeling tot de gemeenschap behorende goederen moet geschieden naar hun waarde op dat ogenblik. Partijen kunnen van dit uitgangspunt afwijken. ${ }^{9}$ Ook uit de redelijkheid en billijkheid kan anders voortvloeien. Zo heeft de Hoge Raad beslist in het kader van de verdeling van een door echtscheiding ontbonden huwelijksgemeenschap. ${ }^{10}$

Bij het uitgangspunt dat de waardering van goederen van de gemeenschap van nalatenschap moet geschieden naar hun waarde op het tijdstip van verdeling, sluit aan dat bij de vaststelling van de verdeling door de rechter als peildatum voor de waardering de datum van de uitspraak het meest in aanmerking komt. ${ }^{11}$

\subsection{Waardering en wijze van verdelen en redelijkheid en billijkheid.}

De wet geeft niet aan welke waarde bij de verdeling van goederen dient te worden gehanteerd. En ook aan deskundigen, aangewezen door de deelgenoten of hun wettelijke vertegenwoordigers of benoemd door de rechter, geeft de wet geen richtsnoer mee. ${ }^{12}$

Van Mourik heeft gepleit voor de rechtssfeerwaarde, waarmee hij bedoelt de waarde welke wordt bepaald met inachtneming van de rechtssfeer waarin het te verdelen goed zich bevindt. ${ }^{13}$ Zo bevindt een door de erflater met

7 Zie daarover Asser/Perrick 3-V 2019/6.

8 Volgens HR 20 december 1991, ECLI:NL:HR:1991:ZC0456, NJ $1992 / 624$ is deze regel neergelegd in art. 3:172 BW, op grond waarvan de deelgenoten naar evenredigheid van hun aandelen delen in de andere vruchten en voordelen die een gemeenschappelijk goed oplevert.

9 Bij nalatenschappen waarin uitsluitend de langstlevende en de kinderen en/of kleinkinderen zijn gerechtigd wordt, vooral wanneer alle goederen en schulden aan de langstlevende echtgenoot worden toebedeeld en de (klein)kinderen een vordering tot gelijkmaking op de langstlevende verkrijgen, dikwijls van de hoofdregel afgeweken en vindt waardering per de datum van overlijden van erflater plaats. Ook in geval van een wettelijke verdeling van de nalatenschap vindt de waardering per sterfdag plaats.

10 HR 6 september 1996, ECLI:NL:HR:1996:ZC2130, NJ 1997/593 en HR 17 april 1998, ECLI:NL:HR:1998:ZC2631, NJ 1999/550. Zie ook HR 22 maart 1996, ECLI:NL:HR:1996:AD2515, NJ 1996/710.

11 Zie HR 22 september 2000, ECLI:NL:HR:2000:AA7205, NJ 2000/643, HR 24 juni 2005, ECLI:NL:HR:2005:AS8447 en HR 8 december 2006, ECLI:NL:HR:2006:AZ0760, NJ 2006/660.

12 Zie over de waarde bij de verdeling van de nalatenschap uitgebreid W. Burgerhart, Waarde en erfrecht (Publicaties vanwege het Centrum voor Notarieel Recht), Deventer: Kluwer 2008/5.11 en hoofdstuk 7.

13 M.J.A. van Mourik, Het begrip 'waarde' in het privaatrecht en enige fiscale wetten, WPNR 1979, afl. 5494. 
zijn echtgenoot bewoond huis zich in een ander soort gemeenschap dan het woonhuis dat twee beleggers gezamenlijk hebben verworven ter belegging. De rechtssfeer bepaalt wat de eisen van redelijkheid en billijkheid vereisen.

Bij de verdeling van de gemeenschap van nalatenschap zal rekening moeten worden gehouden met wat voor de betrokken deelgenoot de waarde is van het toebedeelde. In de praktijk en de rechtspraak doet zich een gevarieerde casuïstiek voor. ${ }^{14}$ Ik volsta met enkele voorbeelden. Een door de erflater met zijn echtgenoot bewoond huis moet, ook bij toedeling aan de echtgenoot, gewaardeerd worden als een huis dat bij levering leeg opgeleverd wordt, dit is voor de echtgenoot de waarde. ${ }^{15}$ Een klassiek voorbeeld ${ }^{16}$ is het stel vazen waarvan één tot de nalatenschap behoort en de twee andere aan één van de erfgenamen toebehoren. Deze kan op grond van de redelijkheid en billijkheid, die de erfgenamen/deelgenoten jegens elkander moeten betrachten, toedeling aan hem van de hem ontbrekende vaas verlangen, doch hij zal dan moeten aanvaarden dat hem de waarde die de vaas voor hem heeft, in rekening wordt gebracht. Wanneer tot de nalatenschap een meerderheid van aandelen in een nv of bv behoort, zal de wijze waarop de toedeling plaatsvindt mede de waarde bepalen van de toebedeelde aandelen; voor de ene erfgenaam kunnen zij een andere waarde hebben dan voor de andere erfgenaam. ${ }^{17}$ Wanneer de redelijkheid en billijkheid meebrengen dat de boerderij waarop een zoon sinds jaren werkzaam is, aan hem wordt toebedeeld, dan zal in de regel de waarde waarvoor hem de boerderij wordt toebedeeld lager zijn dan de waarde die de boerderij voor de andere erfgenaam/erfgenamen heeft. De voortzettende zoon, die de boerderij krijgt toebedeeld, krijgt niets anders dan een bron van inkomsten. Bij de waardering wordt het rendement van de boerderij betrokken en de boerderij zal aan de op de boerderij werkzame erfgenaam worden toebedeeld voor een zodanige waarde dat een rendabele exploitatie nog juist mogelijk is.

\section{Doorwerking redelijkheid en billijkheid na verdeling}

Ten gevolge van de verdeling van de goederen van de gemeenschap van nalatenschap houden de erfgenamen op deelgenoten te zijn. Artikel 3:166 lid 3 in verbinding met artikel 6:2 BW geldt niet voor de ex-deelgenoten. Dat wil niet zeggen dat de redelijkheid en de billijkheid na de verdeling de rechtsverhouding tussen de deelgenoten niet mede bepalen. Men realisere zich daarbij allereerst dat de verdeling een meerzijdige rechtshandeling is. Dat betekent dat op grond van artikel 6:216 BW onder meer artikel 6:248 lid 2 BW van toepassing is, met als gevolg dat een bij de verdeling overeengekomen bepaling 'niet van toepassing [is] voor zover dat in de gegeven omstandigheden naar maatstaven van redelijkheid en billijkheid onaanvaardbaar zou zijn'. Een bepaling van de verdeling waarvoor dit van belang kan zijn, is de bepaling in de akte van verdeling dat de deelgenoten afstand doen van het recht om vernietiging of herrekening te vorderen en dat de deelgenoten niets meer van elkander te vorderen hebben en elkaar volledig kwijten en dechargeren. Komt een deelgenoot er na het tekenen van de akte van verdeling achter dat hij de vernietiging van de verdeling kon inroepen, dan is de afstand van het recht van vernietiging te vorderen naar mijn mening ongeldig. Deze deelgenoot kan zich ook op artikel 6:248 lid 2 BW beroepen. ${ }^{18}$
14 Zie daarover Asser/Perrick 3-V 2019/147 en M.J.A. van Mourik \& F.W.J.M. Schols, Gemeenschap (Mon. BW nr. B9), Deventer: Wolters Kluwer 2015/49.

15 Aldus ook HR 13 december 1995, ECLI:NL:HR:1995:AA3167, BNB 1996/70.

16 Ontleend aan Pitlo/Van der Burght \& Ebben 2004/585.

17 Zie ook Parl. Gesch. Boek 3 1981, p. 619, waar de minister in het kader van de vaststelling van (de wijze van) de verdeling door de rechter opmerkt dat het volgens art. 3:185 lid $1 \mathrm{BW}$ aan het oordeel van de rechter is overgelaten of het billijk zou zijn om een deelgenoot, voor wie een goed een bijzondere waarde heeft, een hogere waarde in rekening te brengen dan het, afgezien van deze omstandigheid, in het economisch verkeer heeft. Zie ook Asser/Perrick 3-V 2019/187. 